\title{
PEMANFAATAN KOMIK STRIP \\ SEBAGAI MEDIA PEMBELAJARAN MAHASISWA PENDIDIKAN EKONOMI UM METRO
}

\author{
Triani Ratnawuri \\ Pendidikan Ekonomi FKIP Universitas Muhammadiyah Metro \\ triani_rw@yahoo.co.id
}

\begin{abstract}
Abstrak
Perkembangan ilmu pengetahuan dan teknologi semakin mendorong pemanfaatan hasil-hasil teknologi dalam kegiatan pembelajaran. Salah satunya adalah pemanfaatan media pembelajaran sebagai sarana penunjang kegiatan pembelajaran guna tercapainya tujuan pembelajaran secara optimal. Berdasarkan fenomena yang terdapat pada mahasiswa pendidikan ekonomi untuk mata kuliah manajemen keuangan yang hasil belajarnya belum optimal, maka diperlukan pemanfaatan media pembelajaran berupa media komik strip. Komik strip dimanfaatkan sebagai media pembelajaran karena diduga sesuai untuk menggambarkan materi pembelajaran agar dapat membantu memudahkan pemahaman mahasiswa. Pendekatan penelitian ini adalah penelitian kuantitatif metode eksperimen, dengan desain eksperimen semu atau quasi eksperimental design bentuk nonequivalent control group design. Teknik pengumpulan data yang digunakan adalah observasi, dokumentasi, angket, dan tes. Teknik yang digunakan untuk menganalisis data adalah t-test dua sampel independen. Pemanfaatan media komik strip mempengaruhi hasil belajar ditunjukkan dengan nilai signifikansi uji $\mathrm{t}$ adalah 0,000 . Nilai signifikansi tersebut kurang dari 0,05 yang berarti bahwa $\mathrm{H}_{1}$ tidak ditolak serta nilai t hitung adalah sebesar 5,508 > dari $\mathrm{t}$ tabel yaitu sebesar 1,99. Sehingga pemanfaatan komik strip sebagai media pembelajaran memiliki pengaruh yang signifikan terhadap hasil belajar.
\end{abstract}

Kata kunci: komik strip, media pembelajaran, hasil belajar

\section{PENDAHULUAN}

Berbagai upaya dalam menciptakan proses pembelajaran yang berkualitas demi mewujudkan tujuan pendidikan nasional. Salah satunya dengan memanfaatkan sarana dan prasana pendidikan yang dapat mendukung perkuliahan. Dalam kemajuan perkembangan ilmu pengetahuan dan teknologi semakin mendorong berbagai upaya untuk memanfaatkan hasil-hasil teknologi. Dengan hasil teknologi dapat mendorong pelaksanaan pembelajaran menjadi lebih mudah dan berkualitas.

Program studi pendidikan ekonomi di Universitas Muhammadiyah Metro sebagai salah satu bagian penyelenggaraan pendidikan, bertujuan untuk membentuk calon guru ekonomi yang berkualitas. Dalam pelaksanaan pembelajaran mahasiswanya juga memerlukan upaya untuk proses pembelajaran yang baik dan berkualitas. Namun, kenyataannya pelaksanaan dari perencanaan pembelajaran masih menemukan banyak kendala, terutama dalam penyampaian materi perkuliahan. Untuk itu diperlukan alat bantu yang mempermudah dosen dalam menyampaikan materi dan mahasiswa dalam memahami materi perkuliahan.

Masalah yang ditemui pada saat proses pembelajaran masih banyak terdapat kendala, yaitu mahasiswa kurang aktif dan kurang termotivasi untuk belajar, kurang aktif dalam bertanya dan tidak fokus 
dengan penjelasan pada saat diskusi, banyaknya mahasiswa mengobrol, mengantuk, dan mengabaikan proses pembelajaran di kelas, sehingga berdampak pada hasil belajar yang rendah. Berbagai masalah dalam proses pembelajaran ini diduga disebabkan oleh pelaksanaan perkuliahan oleh dosen yang kurang memanfaatkan sarana dan prasarana untuk menarik perhatian mahasiswa. Sehingga belum tercipta proses pembelajaran yang efektif dan ideal.

Keberhasilan dalam proses pembelajaran sebaiknya memuat tiga komponen pembelajaran yaitu guru atau pengajar, materi pembelajaran, dan siswa atau mahasiswa, serta melibatkan sarana dan prasarana seperti berbagai metode, media pembelajaran dan penataan lingkungan. Pemanfaatan media pembelajaran sebagai salah satu upaya untuk pelaksanaan pembelajaran yang lebih mudah dan berkualitas dapat menjadi salah satu solusi dari kendala yang ditemui pada saat perkuliahan.

Berdasarkan masalah yang terjadi untuk memperbaiki proses pembelajaran, diperlukan upaya dengan memanfaatkan media pembelajaran sebagai alat bantu. Media pembelajaran yang digunakan adalah komik strip, karena komik strip diduga sesuai untuk menggambarkan cerita tentang materi pembelajaran. Dengan komik strip diharapkan dapat menyampaikan materi pembelajaran menjadi lebih mudah dan menarik perhatian mahasiswa. Sehingga rumusan masalah dalam penelitian ini adalah: "Apakah ada pengaruh pemanfaatan komik strip sebagai media pembelajaran terhadap hasil belajar mahasiswa?"

\section{TINJAUAN PUSTAKA}

\section{Hasil Belajar}

Sudjana (2009:22) mendefinisikan hasil belajar sebagai kemampuan-kemampuan yang dimiliki siswa setelah ia menerima pengalaman belajarnya. Hasil belajar yang dimaksud dalam penelitian ini adalah hasil belajar mahasiswa yang diperoleh dari tes formatif setelah diberikan perlakuan berupa pemanfaatan komik strip sebagai media pembelajaran.

\section{Komik Strip}

Komik strip (strip comics) didefinisikan oleh Arjuna (2011:3) sebagai sebuah gambar atau rangkaian gambar yang berisi cerita. Gambar-gambar dirangkai dalam komik strip terdiri dari tiga sampai enam panel. Gambar tersebut dirangkai dengan muatan cerita tertentu.

Komik yang bisa dikatakan sebagai media pembelajaran apabila isi cerita komiknya memenuhi unsur-unsur pembelajaran, sehingga tidak hanya memiliki aspek menghibur. Komik pembelajaran juga harus bisa memenuhi tujuan instruksional atau tujuan pembelajaran dari setiap materi yang diceritakan dalam isinya, yaitu memuat materi pembelajaran sesuai dari pokok bahasan materi yang akan disampaikan.

Komik sebagai media pembelajaran yang edukatif, mempunyai sifat yang sederhana, jelas, mudah dan bersifat personal. Komik merupakan suatu kartun yang mengungkapkan sebuah karakter dan memerankan cerita dalam urutan yang erat, dihubungkan dengan gambar dan dirancang untuk memberikan hiburan kepada para pembaca. Peranan pokok komik dalam instruksional adalah kemampuannya dalam menciptakan minat peserta didik (Rohani, 2014:77-79). 
Berdasarkan beberapa definisi tentang komik sebagai media pembelajaran, dapat disimpulkan bahwa komik strip merupakan salah satu media pembelajaran yang dapat digunakan untuk mengatasi permasalahan dalam memahami suatu materi pelajaran. Sehingga komik juga tidak hanya dapat meningkatkan minat baca peserta didik, tapi juga dapat memotivasi peserta didik terhadap materi pembelajaran yang diajarkan, dengan harapan akan memberikan dampak yang positif terhadap hasil belajar.

Bentuk komik dalam penelitian ini adalah komik strip yang dimanfaatkan sebagai media pembelajaran bagi mahasiswa pendidikan ekonomi pada mata kuliah manajemen keuangan dengan materi ajar nilai uang terhadap waktu. Materi pembelajaran dimuat dalam rangkaian gambar komik yang berisi cerita sederhana gambaran kehidupan sehari-hari untuk dapat membantu mahasiswa lebih mudah memahaminya.

\section{METODE PENELITIAN}

Desain penelitian ini adalah eksperimen semu quasi eksperimental design dengan bentuk nonequivalent control group design. Pendekatan penelitian kuantitatif dengan desain eksperimen semu digunakan dalam penelitian ini karena dalam pelaksanaan penelitian, peneliti tidak dapat mengontrol seluruh variabel. Gambar desain Quasi eksperimental design bentuk nonequivalent control group design, adalah sebagai berikut:

\section{Gambar 1. Desain Quasi eksperimental design bentuk nonequivalent control group design}

\begin{tabular}{|lll|}
\hline $\mathrm{O}_{1}$ & $\mathrm{X}$ & $\mathrm{O}_{2}$ \\
$\mathrm{O}_{3}$ & & $\mathrm{O}_{4}$ \\
\hline
\end{tabular}

Keterangan:

$\mathrm{X}$

$$
\begin{aligned}
& \text { : perlakuan yang } \\
& \text { diberikan }
\end{aligned}
$$

O1 dan $\mathrm{O}_{3}$ : pretes pada tiap kelas

$\mathrm{O}_{2}$ danO4 : postes pada tiap kelas

(Sugiyono 2011: 118).

Desain eksperimen ini terdapat dua kelas yaitu kelas eksperimen (O1) dan kelas kontrol $\left(\mathrm{O}_{2}\right)$. Sebelum dilakukan penelitian masing-masing kelas diberi pretes untuk mengetahui kemampuan awal kedua kelas tersebut. Pada kelas eksperimen diberi perlakuan (X) dengan pemanfaatan komik strip sebagai media pembelajaran. Sedangkan pada kelas kontrol menerapkan model pembelajaran konvensional. Selanjutnya kedua kelas diberi postes untuk mengetahui pengaruh perlakuan yang telah diberikan.

Metode penelitian yang digunakan dalam penelitian ini yang pertama yaitu pengamatan atau observasi adalah proses pengambilan data dalam penelitian dimana peneliti atau pengamat melihat situasi penelitian (Kusumah, 2010:66). Sebagai data penunjang dalam penelitian ini diperlukan lembar observasi yang penelitian ini adalah untuk mengamati aktivitas mahasiswa selama proses pembelajaran berlangsung.

Setelah tahap pengamatan atau observasi dilaksanakan makan tahap selanjutnya adalah dokumentasi dimana menurut Hamdani (2008:77) dokumentasi 
berupa dokumen-dokumen baik berupa dokumen primer maupun dokumen sekunder yang menunjang proses pembelajaran di kelas. Dokumen yang digunakan sebagai data penunjang dalam penelitian ini berupa foto, catatan observasi, maupun tulisan yang diperoleh pada saat proses pembelajaran di kelas.

Tahap terakhir dalam metode pengumpulan data dalam penelitian ini ialah metode tes, dimana tes merupakan serentetan pertanyaan atau latihan serta alat lain yang digunakan untuk mengukur keterampilan, pengetahuan intelegensi, kemampuan atau bakat yang dimiliki oleh individu atau kelompok (Arikunto, 2010:193). Tes yang dimaksud dalam penelitian ini adalah tes formatif secara tertulis untuk menguji materi pokok bahasan pada saat sebelum da sesudah perlakuan. Hasil dari tes yang diperoleh merupakan data utama pada penelitian ini untuk mengetahui hasil belajar.

Setelah proses metode pengambilan data telah semua terlaksana tahap selanjutnya dalam penelitian ini yaitu teknik analisis data, dimana dalam penelitian ini mengguanakan rumus T-Test Dua Sampel Independen. Terdapat beberapa rumus ttest yang dapat digunakan untuk pengujian hipotesis komparatif dua sampel independen.

Pengujian hipotesis dalam penelitian ini:

Tolak $\mathrm{H}_{\mathrm{o}}$ apabila $\mathrm{F}_{\text {hitung }}>\mathrm{F}_{\text {tabel }}$; $\mathrm{t}_{\text {hitung }}>\mathrm{t}_{\text {tabel }}$ Terima $\mathrm{H}_{\mathrm{a}}$ apabila $\mathrm{F}_{\text {hitung }}<\mathrm{F}_{\text {tabel }} ; \mathrm{t}_{\text {hitung }}<$ $t_{\text {tabel }}$

\section{PEMBAHASAN HASIL PENELITIAN}

Berdasarkan fenomena yang terdapat pada mahasiswa pendidikan ekonomi yang belum secara optimal mencapai tujuan pembelajaran dengan hasil belajar yang belum optimal, maka diperlukan perlakuan yang dapat meningkatkan hasil belajar mahasiswa. Salah satunya dengan memanfaatkan media dalam proses pembelajaran.

Komik strip sebagai salah satu media pembelajaran dipilih untuk dimanfaatkan dalam pembelajaran karena komik strip dapat menjadi media yang akan menarik perhatian mahasiswa untuk lebih aktif dalam mendalami materi sehingga motivasi belajar mahasiswa pun menjadi lebih tinggi. Contoh tampilan media komik strip yang digunakan dalam penelitian ini dapat dilihat pada gambar 2 .

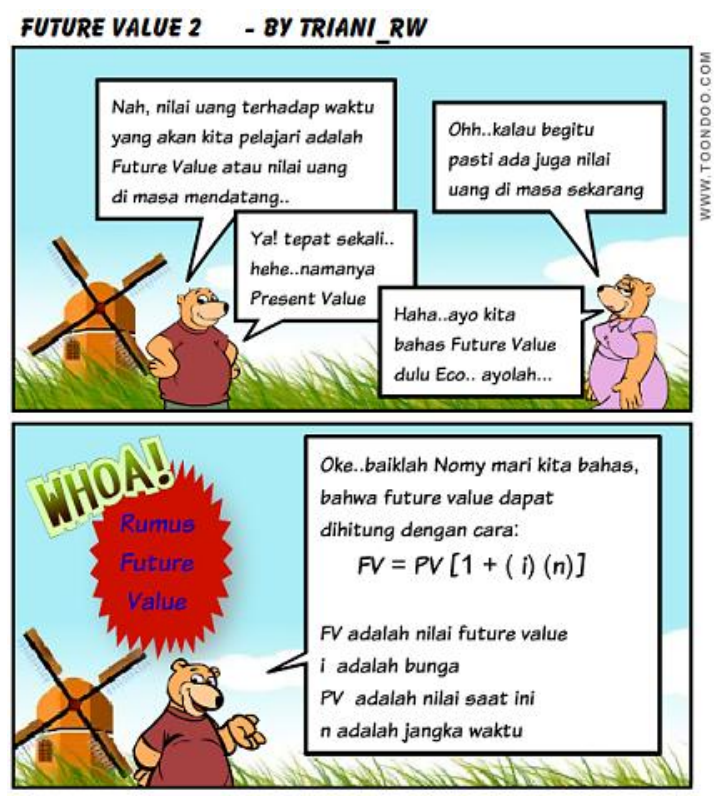

Gambar 2. Tampilan komik strip

Hasil analisis data menunjukkan bahwa skor rata-rata nilai keterampilan kelas eksperimen mengalami peningkatan sebesar 22,79\% sedangkan pada kelompok kontrol mengalami peningkatan $7,88 \%$. Selanjutnya untuk nilai mean posttes kelas eksperimen adalah 79,26 dan nilai mean kelas kontrol adalah 65,61. Sehingga dapat dibuktikan bahwa kelas eksperimen yang 
mendapat perlakuan memiliki hasil yang lebih unggul dari pada kelas kontrol.

Berdasarkan hasil uji posttest kelas kontrol dan eksperimen nilai signifikansi uji $t$ adalah 0,000. Nilai signifikansi tersebut kurang dari 0,05 yang berarti bahwa $\mathrm{H}_{1}$ tidak ditolak serta nilai $\mathrm{t}$ hitung $5,508>$ dari t tabel yaitu sebesar 1,99. Hal ini menunjukkan terdapat perbedaan yang signifikan rata-rata nilai hasil belajar mahasiswa antara kelas kontrol dan kelas eksperimen. Sehingga peningkatan hasil belajar lebih baik pada kelas eksperimen yang menerapkan pemanfaatan komik strip sebagai media pembelajaran dibandingkan dengan kelas kontrol.

Berdasarkan hasil dan pembahasan penelitian dapat disimpulkan bahwa pemanfaatan media komik strip berpengaruh terhadap hasil belajar ditunjukkan dengan nilai signifikansi uji $\mathrm{t}$ adalah $0,000<\mathrm{i} 0,05$ yang berarti bahwa $\mathrm{H}_{1}$ tidak ditolak serta nilai $\mathrm{t}$ hitung adalah sebesar 5,508>1,99 nilai t tabel. Sehingga pemanfaatan komik strip sebagai media pembelajaran memiliki pengaruh yang signifikan terhadap hasil belajar.

Berdasarkan penelitian yang sudah dilaksanakan, peneliti menyarankan kepada pendidik untuk pelaksanaan pembelajaran dapat diterapkan kembali dengan lebih bervariasi disesuaikan oleh kebutuhan pembelajaran. Dengan harapan meningkatkan kualitas pembelajaran sehingga dapat juga meningkatkan motivasi belajar dan hasil belajar mahasiswa.

\section{DAFTAR PUSTAKA}

Arikunto, Suharsimi. 2010. Prosedur Penelitian. Jakarta: Rineka Cipta

Arjuna. 2011. "Komik Sebagai Media Pembelajaran". Artikel. Diakses dari

http://arjunabelajar.blogspot.com/ 2011/03/komik-sebagaimediapembelajaran.html

Hamdani, Nizar Alam dan Dodi Hermana. 2008. Classroom Action

Research, Teknik Penulisan dan Contoh Proposal Penelitian Tindakan Kelas (PTK). Jakarta. Rahayasa Research and Training.

Kusumah, Wijaya dan Dedi Dwitagama. 2010. Mengenal Penelitian Tindakan Kelas. Jakarta: Indeks

Rohani, Ahmad. 2014. Media Intruksional Edukatif. Jakarta: Rineka Cipta

Sudjana, Nana. 2009. Penilaian Hasil Proses Belajar Mengajar. Bandung: Remaja Rosdakarya

Sugiyono,2011. Metode Penelitian Kuantitif, Kualitatif dan R \& D. Bandung: Alfabeta 